\title{
Evaluation of Native AMF Population for Drought Stress Ameliorating Potential in Finger Millet
}

\author{
Pallavi* and A.K. Sharma \\ Department of Biological Sciences, College of Basic Science and Humanities, \\ Govind Ballabh Pant University of Agriculture and Technology, Pantnagar, \\ U.S Nagar-263145, Uttarakhand, India \\ *Corresponding author
}

\section{A B S T R A C T}

\section{Keywords}

Water uptake, growth, Plant nutritional status, Protein, Fat, Minerals

\section{Article Info}

Accepted:

12 October 2019

Available Online:

10 November 2019

Finger millet is a very important crop because of its resilience against adverse climatic conditions. It is well adapted to higher elevations, drought tolerant, disease resistant and able to grow on marginal lands with poor soil fertility, which reflects in having highest productivity among millets. Also, it is a good source of protein, fat, and minerals. All these factors make it suitable especially among the segment of low-income group populations. Arbuscular mycorrhizal fungi (AMF) are capable of reducing the adverse effects of drought on plants. Recently, there is a growing interest in the Finger millet-AMF symbiosis in relation to enhancing water uptake, growth, plant nutritional status and yield. However, to our knowledge, there is no study performed related to the application of native mycorrhizal population in improving drought tolerance of finger millet. Native mycorrhiza inoculation resulted enhanced biomass production compared to than nonmycorrhizal finger millet plants, irrespective of soil water status. In addition, AMF inoculation led to significantly higher nutrient and biochemical status of plants. Our results support the idea of exploiting native mycorrhizal population in improving the drought tolerance of finger millet plants.

\section{Introduction}

Among all the rhizospheric microbes, arbuscular mycorrhizal fungi (AMF) are the most interesting, incapable of living without their host plants, they form the most abundant of symbiotic association on earth. The AMF belong to the phylum Glomeromycota and are represented by 230 species (Oehl et al., 2011). The mutualistic association of AMF with most of the vascular plant roots results in increased uptake of water, inorganic nutrients, enhanced tolerance to many environmental stress and protection from pathogens for the host and in reward of this, fungus gets the carbon assimilates from host, essential for its survival (Smith and Read, 1997). It is evident by many studies that AMF are crucial for the functioning of terrestrial ecosystems. Not only their presence but also their genetic and functional diversities are of importance: AMF diversity can be decisive for both plant 
community structure and ecosystem productivity (der Heijden and Scheublin, 2007).

Farmers can take better advantage of the AM symbiosis in two ways: through management of the community of AM fungi indigenous to their soils or through inoculation with effective isolates of AM fungi (Bagyaraj 1992). Also, AMF inoculation from somewhere else can suppress and can cause extinction of locally adapted species (Friberg, 2001). An alternative to purchasing inocula is for the farmer to produce it him/herself onfarm. These methods were first developed for the tropics (Gaur 1997; Gaur and Adholeya 2000; Maiti et al., 2009).

Finger millet is an underutilized crop of tropics with high nutritional value. Recently, it has gained interest of researchers because of its ability to withstand water deficient condition. The current study was performed to evaluate the potential of native AMF population in ameliorating harmful effects of water stress condition in finger millet. It was considered if they are able to improve the growth and stress tolerance of a drought resilient crop, they will definitely be able to benefit susceptible crops. Monoculture of $R$. intraradices was selected as positive control because of its wide commercial application.

\section{Materials and Methods}

\section{Inoculum preparation}

The study was conducted using soil of six agricultural lands located at different altitudes of Kumaun Himalayas (Table 1). Four cores of $20 \mathrm{~cm}$ depth with $100 \mathrm{~g}$ of rhizosphere soil was taken from each sites, collected and pooled in polybags to form a composite sample. To maximize the inoculum potential and encourage sporulation by AMF species present in soil samples, we cultured AMF in the greenhouse using a highly mycotrophic host plants, Maize, Sorghum and Cowpea. Since we had no information about the native AMF community we utilized the trap culture method using three plants instead of one crop to provide viable AMF propagules their best host for symbiosis to happen efficiently. Potting mixture included $200 \mathrm{gm}$ soil sample with autoclaved mixture of vermiculite and gravel (2:1). After 60 days, the plants were left for drying to enhance sporulation. Potting substrate after 8 such cycles was used as the inoculum for the study.

\section{Pot experiment to evaluate the effect of indigenous mycorrhiza}

Finger millet (var. PRM1) collected from Hill campus GBPUA\&T, Ranichauri was selected for the study. The soil and sand (1:5) were sterilized (autoclaved for $2 \mathrm{~h}$ at $120{ }^{\circ} \mathrm{C}$ for three consecutive days) and used as potting mixture. The trap soil of each location after eight cycles was used as inoculum representing the native AMF diversity (Inoculum equivalent to 100 spores per seed was given).

Monoculture Rhizophagus intraradices was taken as positive control. Moisture level of potting substrate was maintained at $90 \%$ for 55 days by weighing the pots and adding water according to the weight loss. Two sets of pots were set up for each inoculum one for irrigated and another for drought condition. Fertilization with Hoagland solution (Phosphorus strength- 1/4) was done after one month of sowing seeds. After 55 days, one set was subjected to drought by withholding water till the water holding capacity (WHC) was at $50 \%$ and harvesting was done. For biochemical parameters tissue was sampled on ice and stored at $-80^{\circ} \mathrm{C}$. Parameters measured were plant biomass, length, shoot nutrient uptake $(\mathrm{N}, \mathrm{P}, \mathrm{K}, \mathrm{Ca}, \mathrm{Na})$, proline content, superoxide dismutase (SOD) activity, 
Malonaldehyde (MDA) content and hydrogen peroxide $\left(\mathrm{H}_{2} \mathrm{O}_{2}\right)$ level.

\section{Plant sample collection and analysis}

Plants were harvested after 60 days of sowing and washed thoroughly with tap water. After initial air drying, root/shoot length and root/shoot fresh weight were recorded. Plant samples (root and shoot) were kept in paper bags, dried at $65{ }^{\circ} \mathrm{C}$ in an electric oven until sample weight remained constant. The dry weight of shoots and roots was then assessed.

\section{\% Mycorrhiza frequency}

Roots were first stained by trypan blue method. Root samples were cleared in $\mathrm{KOH}$ solution $(2.5 \%)$ and stained using the Trypan Blue $(0.05 \%)$ and stained as described by (Philips and Hayman 1970). Mycorrhizal colonization was determined by examining 1 $\mathrm{cm}$ root segments $(\mathrm{n}=50$ per each treatment) under the microscope according to Trouvelot et al., (1986). Results are expressed as percentage frequency.

\section{Mineral nutrition}

Dried plant tissues were used for nutrient estimation. The nitrogen content of the leaves was estimated according to Kjeldahl method using the KJELPLUS System (Pelican, India). Diacid digestion of the sample was carried out using 5:1 mixture of $\quad \mathrm{HNO}_{3}: \quad \mathrm{HClO}_{4}$. Phosphorus content was measured by the vando-molybdate phosphate method. Sodium, potassium, and calcium were measured using flame photometer (Systronics Flame Photometer 128).

\section{Determination of water holding capacity (WHC) of soil}

Whatman no. 1 filter paper was placed in the bottom of a porous cup. It was weighed and weight was recorded. Oven dried soil was filled in the cup gently and weight was recorded. Cup was placed into a shallow pan of water for $24 \mathrm{~h}$ allowing only the bottom of the cup to become wet. Soil was allowed to become saturated from the bottom of the cup to the surface. Cup was removed from the pan of water and placed in a humid enclosure for $24 \mathrm{~h}$ until drainage was completed and weight was recorded.

\section{WHC of soil (\%)

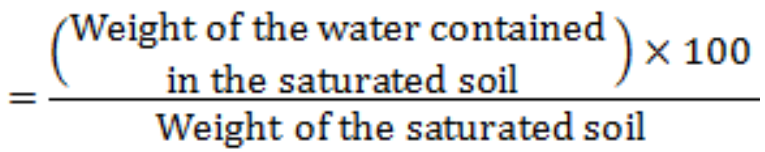

Where,

Weight of the water contained in the saturated soil $=$ Weight of saturated soil - Weight of dry soil

Weight of the saturated soil = Weight of cup, filter paper and saturated soil - weight of cup and filter paper

\section{Biochemical stress markers}

\section{Superoxide dismutase (SOD) activity}

$0.5 \mathrm{~g}$ leaf samples (fresh weight) was homogenized with a pestle in an ice-cold mortar in $5 \mathrm{ml}$ cold buffer containing: $50 \mathrm{mM}$ potassium phosphate buffer $(\mathrm{pH} 7.0), 1 \mathrm{mM}$ ethylene diamine tetra acetic acid (EDTA) and $1 \%(\mathrm{w} / \mathrm{v})$ polyvinylpyrolidone (PVP). Whole extraction procedure was carried out at $4{ }^{\circ} \mathrm{C}$. The homogenate was centrifuged at $10,000 \mathrm{x} \mathrm{g}$ for $30 \mathrm{~min}$ at $4^{\circ} \mathrm{C}$ and the supernatant collected was used to assay enzyme activity. Protein concentration in the enzyme extract was determined by the method of Bradford (1976) using BSA as a standard.

SOD (EC 1.15.1.1) activity was assayed spectrophotometrically as the inhibition of 
photochemical reduction of nitro-blue tetrazolium (NBT) at $560 \mathrm{~nm}$ (Beauchamp and Fridovich, 1971). The reaction mixture $(3 \mathrm{ml})$ consisted of $50 \mathrm{mM}$ Na-phosphate buffer $(\mathrm{pH}$ 7.8), $13 \mathrm{mM}$ L-methionine, $75 \mu \mathrm{M}$ NBT, 10 $\mu \mathrm{M}$ EDTA, $2.0 \mu \mathrm{M}$ riboflavin and $0.1 \mathrm{ml}$ enzyme extract. Test tubes containing the reaction mixture were incubated for $10 \mathrm{~min}$ in 4,000 lux at $35^{\circ} \mathrm{C}$. One unit of SOD activity was defined as the amount of enzyme required to cause a 50\% inhibition of the rate of NBT reduction measured at $560 \mathrm{~nm}$.

\section{Total proline content}

The total proline content was estimated using the method of Bates et al., (1973). Leaf sample $(0.2 \mathrm{~g})$ was homogenized in $2.0 \mathrm{ml}$ of $3 \%$ sulphosalicylic acid (w/v) and the residue was removed by centrifugation. Then, $2.0 \mathrm{ml}$ of extract was reacted with $2 \mathrm{ml}$ glacial acetic acid and $2 \mathrm{ml}$ acid ninhydrin (prepared by warming $1.25 \mathrm{~g}$ ninhydrin in $30 \mathrm{ml}$ glacial acetic acid and $20 \mathrm{ml} 6 \mathrm{M}$ phosphoric acid) for $1 \mathrm{~h}$ at $100^{\circ} \mathrm{C}$. The reaction was terminated by immersion in an ice-bath before the reaction mixture was extracted with $4 \mathrm{ml}$ of toluene. The chromophore containing toluene was warmed to room temperature and its absorbance was measured at $520 \mathrm{~nm}$ and the amount of proline was determined from a standard curve. Results were expressed in $\mu \mathrm{g}$ of free proline $\mathrm{g}^{-1}$ fresh weight.

\section{MDA content}

Leaf material $(0.3 \mathrm{~g})$ was homogenized in 4 $\mathrm{ml}$ of $0.1 \%$ trichloroacetic acid (TCA). Homogenate was centrifuged at $10,000 \mathrm{x}$ g for $10 \mathrm{~min}$ at $4^{\circ} \mathrm{C}$. Procedure of Heath and Packer (1968) was followed to measure the MDA content. Crude extract $(0.3 \mathrm{ml})$ was mixed with $1.2 \mathrm{ml}$ of $0.5 \%(\mathrm{w} / \mathrm{v})$ 2-thiobarbituric acid (TBA) prepared in $20 \%(\mathrm{w} / \mathrm{v})$ trichloroacetic acid (TCA). The mixture was incubated at $95^{\circ} \mathrm{C}$ for $30 \mathrm{~min}$. Reaction was terminated by placing the tubes in ice bath immediately and then centrifuged at $10000 \mathrm{x} \mathrm{g}$ for $10 \mathrm{~min}$. Absorbance of the supernatant was measured at $532 \mathrm{~nm}$ and $600 \mathrm{~nm}$. Absorbance at $600 \mathrm{~nm}$ is subtracted from the absorbance at $532 \mathrm{~nm}$ for non-specific absorbance. The concentration of MDA was calculated by using an extinction coefficient of $155 \mathrm{mM}^{-1}$ $\mathrm{cm}^{-1}$.

\section{$\mathrm{H}_{2} \mathrm{O}_{2}$ content}

Hydrogen peroxide was measured spectrophotometrically after reaction with potassium iodide (KI) according to Alexieva et al., (2001). Reaction mixture was consisted of $0.5 \mathrm{ml}$ of supernatant, $0.5 \mathrm{ml}$ of $0.1 \mathrm{M}$ potassium phosphate buffer and $2 \mathrm{ml}$ of $1 \mathrm{M}$ KI reagent. The blank had $0.1 \%$ TCA in place of leaf extract. The reaction was carried out for $1 \mathrm{~h}$ in darkness and absorbance was measured at $390 \mathrm{~nm}$. The amount of $\mathrm{H}_{2} \mathrm{O}_{2}$ was calculated using standard curve prepared with different dilutions of a working standard of $100 \mu \mathrm{M}$ of $\mathrm{H}_{2} \mathrm{O}_{2}$.

\section{Results and Discussion}

\section{\% mycorrhizal frequency}

Drought stress did not seem to reduce the \% frequency of mycorrhiza occurrence in finger millet roots. All the inoculum resulted in colonization with above $80 \%$ mycorrhizal frequency at the time of harvesting in both well-watered and water stressed conditions (Fig. 1).

\section{Agronomical parameters}

All the inoculum significantly enhanced the shoot length with equal extent (Fig. 2) highest recorded in Nachini with $19 \%$ increase over control plants in drought condition and $15 \%$ increase over control plants in irrigated condition. Inoculation of 
finger millet plants with AMF (both native population and $R$. intraradices) significantly improved shoot fresh weight under both drought (8 \% - $34 \%)$ and irrigated conditions (10 \% $\quad-29.7 \%)$. Nachini, Dwarson and $R$. intraradices were the most effective inoculum (Fig. 3). In terms of shoot dry weight also, Nachini (40\% increase in drought condition and $31 \%$ in irrigated conditions) and $R$. intraradices (24 $\%$ increase in drought condition and $37 \%$ in irrigated conditions) were the most effective inoculum (Fig. 4). AMF inoculation resulted in enhanced root parameters irrespective of water conditions over non-mycorrhized control plants. Dharanaula $(12.3 \%)$ and $R$. intraradices $(14.1 \%)$ being the most effective inoculum in improving root length (Fig. 5). On the other hand, root fresh weight (Fig. 6) was recorded highest in Dwarson (28.7\% increase) in drought condition followed by Nachini (22.7 \%) and under irrigated conditions, $R$. intraradices treated plants recorded $36 \%$ increase over control followed by Nachini (31.6 \%). Root dry weight (Fig. 7) of plants inoculated with Nachini inoculum showed highest increase over control plants under drought conditions, however, under irrigated conditions, $R$. intraradices was most effective followed by Chandak and Dwarson.

\section{Mineral nutrition}

Nutrient analysis of irrespective of inoculum, shoot tissue showed that the water stress resulted in significant reduction of $\mathrm{N}$ (18.1\%), P (20\%), K $\mathrm{K}^{+}(9.6 \%), \mathrm{Ca}^{++}(13.8 \%)$ and $\mathrm{Na}^{+}(27.2 \%)$ levels compared to irrigated plants. However, inoculation with both native and exotic AMF significantly enhanced N (27.4-36.3\%), P (11-37.1\%), $\mathrm{K}^{+}$ (24.3-34.9\%), $\mathrm{Ca}^{++}(2.3-45.5 \%)$ contents of finger millet under drought stress. Similarly, in non-stressed conditions as well the inoculation with AMF resulted in increased foliar nutrient content, $\mathrm{N}(19.8-23.3 \%), \mathrm{P}$ (4.0-44.5\%), $\mathrm{K}^{+}(6.7-29.8 \%), \mathrm{Ca}^{++}(12.0-$ $36.7 \%)$ and $\mathrm{Na}^{+}$of finger millet as compared to non-mycorrhized control plants (Fig. 812).

\section{Biochemical stress markers}

\section{Superoxide dismutase (SOD)}

Under irrigated conditions not much variation was observed in the activity of SOD between inoculated and uninoculated treatments. An increase in the activity of SOD (1.06-1.17fold), was recorded in AMF treated plants under water stress compared to uninoculated control plants (Fig. 13).

\section{Malondialdehyde (MDA) content}

The plants inoculated with native mycorrhiza and monoculture $R$. intraradices on exposure with water stressed conditions, showed reduced MDA levels by $51.3 \%-18 \%$ as compared to water-stressed control plants, indicating that these strains imparted considerable protection against oxidative damage of lipids created by drought.

Highest response was observed in Dwarson inoculum followed by Nachini and $R$. intraradices. In the absence of water stress, MDA content following by AMF inoculation did not show any significant difference over control plants (Fig. 14).

\section{Total proline (Pro) content}

Proline plays crucial role in the process of osmotic adjustment under drought and salinity stress, helps in maintaining favourable osmotic potential for water uptake, thus, alleviating the stress injury. Therefore, proline accumulation is prominent indicator used by researchers for evaluation of stress faced by 
the plants(Wu et al., 2017). Inoculation with AMF, both native and exotic significantly improved proline concentration (up to 1.7fold) in water-stressed plant indicating that AMF improved drought stress tolerance by modulating the proline production. In irrigated conditions as well, there was higher proline content in inoculated plants than the control plants (Fig. 15). Similar findings were reported by Tyagi et al., (2018) in finger millet on inoculation with $R$. intraradices.

\section{Hydrogen peroxide $\left(\mathrm{H}_{2} \mathrm{O}_{2}\right)$}

Drought causes severe oxidative damage and causes accumulation of cellular $\mathrm{H}_{2} \mathrm{O}_{2}$ content, it is another representative of level of stress faced by plants. Inoculation with AMF resulted in reduction of $\mathrm{H}_{2} \mathrm{O}_{2}$ content ranging from a 1.12-1.51-fold under water stressed conditions in comparison to control, however, in irrigated conditions, there was no marked difference between control and AMF inoculation. The accumulation of $\mathrm{H}_{2} \mathrm{O}_{2}$ content was lowest in the Dwarson followed by Nachini (Fig. 16).

There are very limited studies conducted on the interaction of finger millet and AMF. The few that have been performed are based on monoculture AMF. Tewari et al., (1993) observed growth promotion of five finger millet varieties on inoculation with six AMF species, the result showed varied response among the varieties and the effectiveness of different fungi, Glomus caledonicum was found to be the most promising potential.

Since, even with single AMF species variable results are observed, it is understandable that inoculum with mixed AMF population will have differential response. Our results are complying of results reported by Tyagi et al., (2018) showing drought alleviation of finger millet seedlings after AMF inoculation due to improved enzymatic and non-enzymatic activities of mycorrhized plants over nonmycorrhized control. There are no reports of using native AMF for finger millet growth promotion, however as discussed before, studies on several other crops have reported native $\mathrm{AMF}$ are better equipped in combating the stressed conditions over exotic species (Querejeta et al., 2006; Petipas et al., 2017; Harris-Valle et al., 2018).

Our results showed enhanced proline content in mycorrhized plants, in addition to acting as an osmoprotectant, proline also serves as a sink for energy to regulate redox potentials, as a hydroxyl radical scavenger, as a solute that protects macromolecules against denaturation, and as a means of reducing acidity in the cell (Kishor et al., 2005). Plants have evolved several antioxidants mechanisms to avoid oxidative damage linked to stressful conditions. One such enzyme is SOD it rapidly convert superoxide to $\mathrm{H}_{2} \mathrm{O}_{2}$. Enhanced SOD activity under duress helps in mitigating the damage caused by reactive oxygen species, our findings further establishes this in finger millet plants as SOD activity was superior in mycorrhized finger millet plants as compared to non-mycorrhized plants. In addition to increased level of proline and SOD activity, mycorrhized finger millet plants also showed reduction in cellular MDA content, an indicator of reduced lipid peroxidation. The results are in concordance with Zhang et al., 2010, where AMF inoculation in Casuarina equisetifolia decreased the MDA content under drought stress but didn't altered its status under well-watered condition. Essahibi et al., (2018) found drought-stressed AM plants showed decreased hydrogen peroxide and malondialdehyde contents associated with increased activities of superoxide dismutase, ascorbate peroxidase, guaiacol peroxidase, and catalase compared to their relative non mycorrhized carob plants. 
Fig.1 AMF \% mycorrhizal frequency in roots of finger millet plants after the experiment

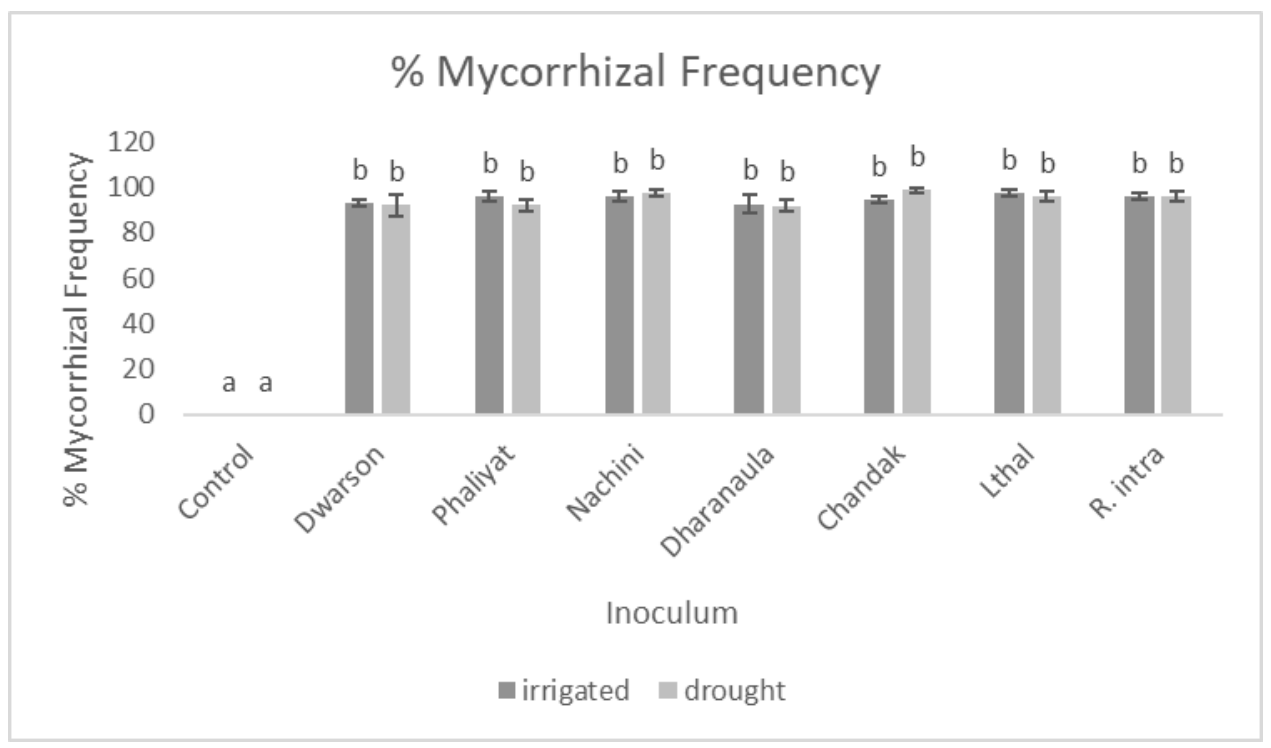

Fig.2 Effect of inoculum developed by trap culturing of native AMF population on the shoot length of finger millet plants under drought and irrigated conditions. Values are the means of 3 replicates \pm S.E. Values with different alphabets are significantly different at $p<0.05$

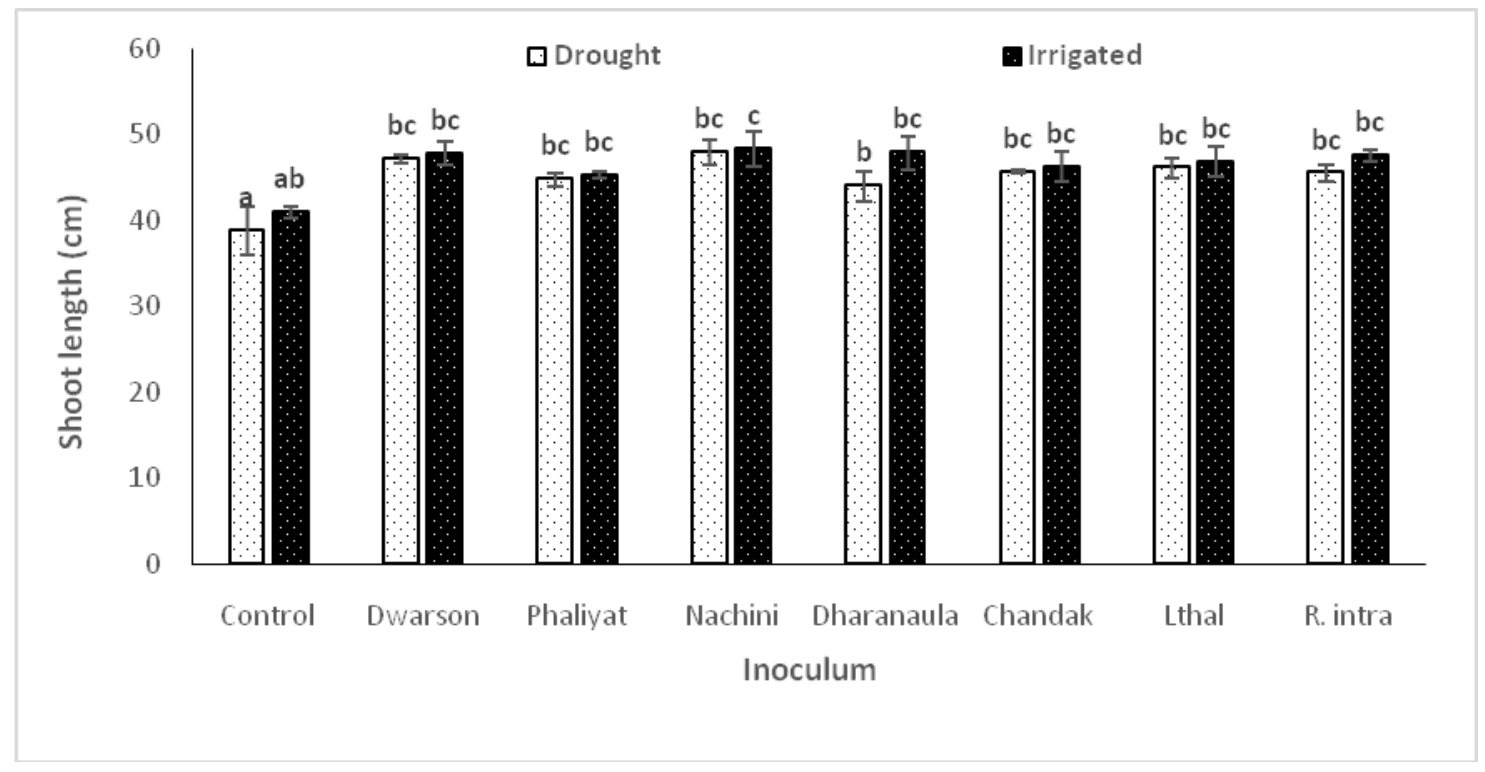


Fig.3 Effect of inoculum developed by trap culturing of native AMF population on the shoot fresh weight of finger millet plants under drought and irrigated conditions. Values are the means of 3 replicates \pm S.E. Values with different alphabets are significantly different at $p<0.05$

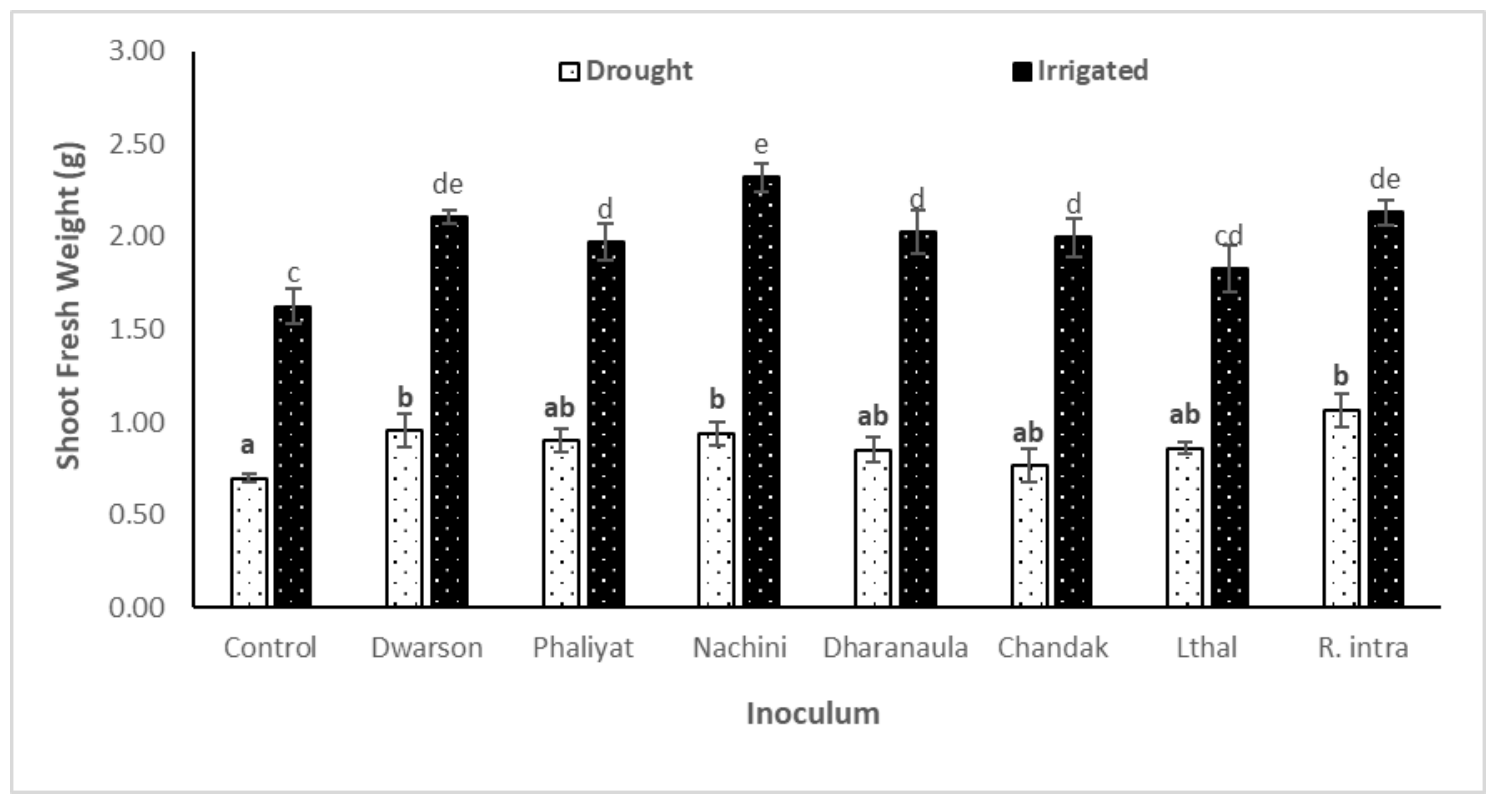

Fig.4 Effect of inoculum developed by trap culturing of native AMF population on shoot dry weight of finger millet plants under drought and irrigated conditions. Values are the means of 3 replicates \pm S.E. Values with different alphabets are significantly different at $\mathrm{p}<0.05$

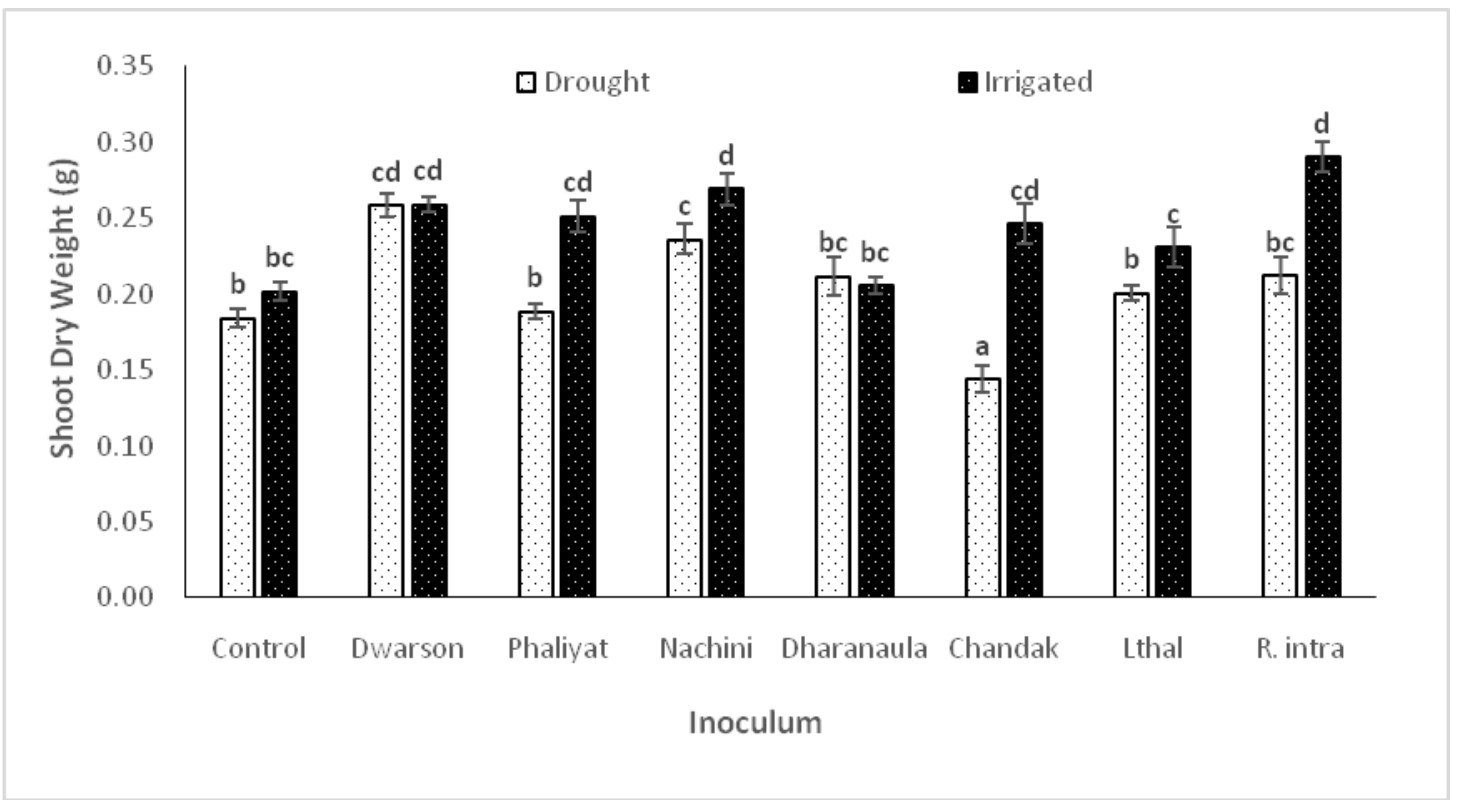


Fig.5 Effect of inoculum developed by trap culturing of native AMF population on the (I) root length of finger millet plants under drought and irrigated conditions. Values are the means of 3 replicates \pm S.E. Values with different alphabets are significantly different at $p<0.05$

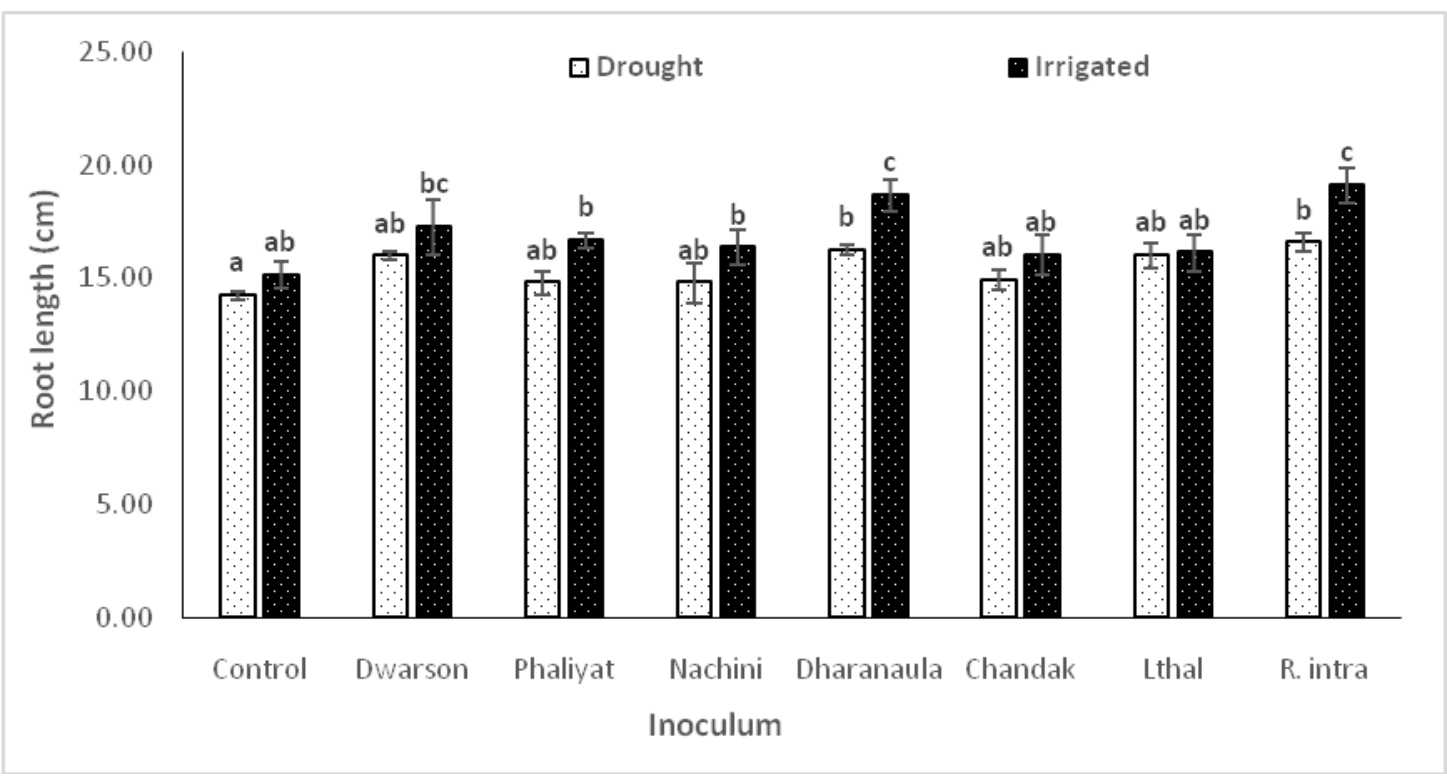

Fig.6 Effect of inoculum developed by trap culturing of native AMF population on the root fresh weight of finger millet plants under drought and irrigated conditions. Values are the means of 3 replicates \pm S.E. Values with different alphabets are significantly different at $\mathrm{p}<0.05$

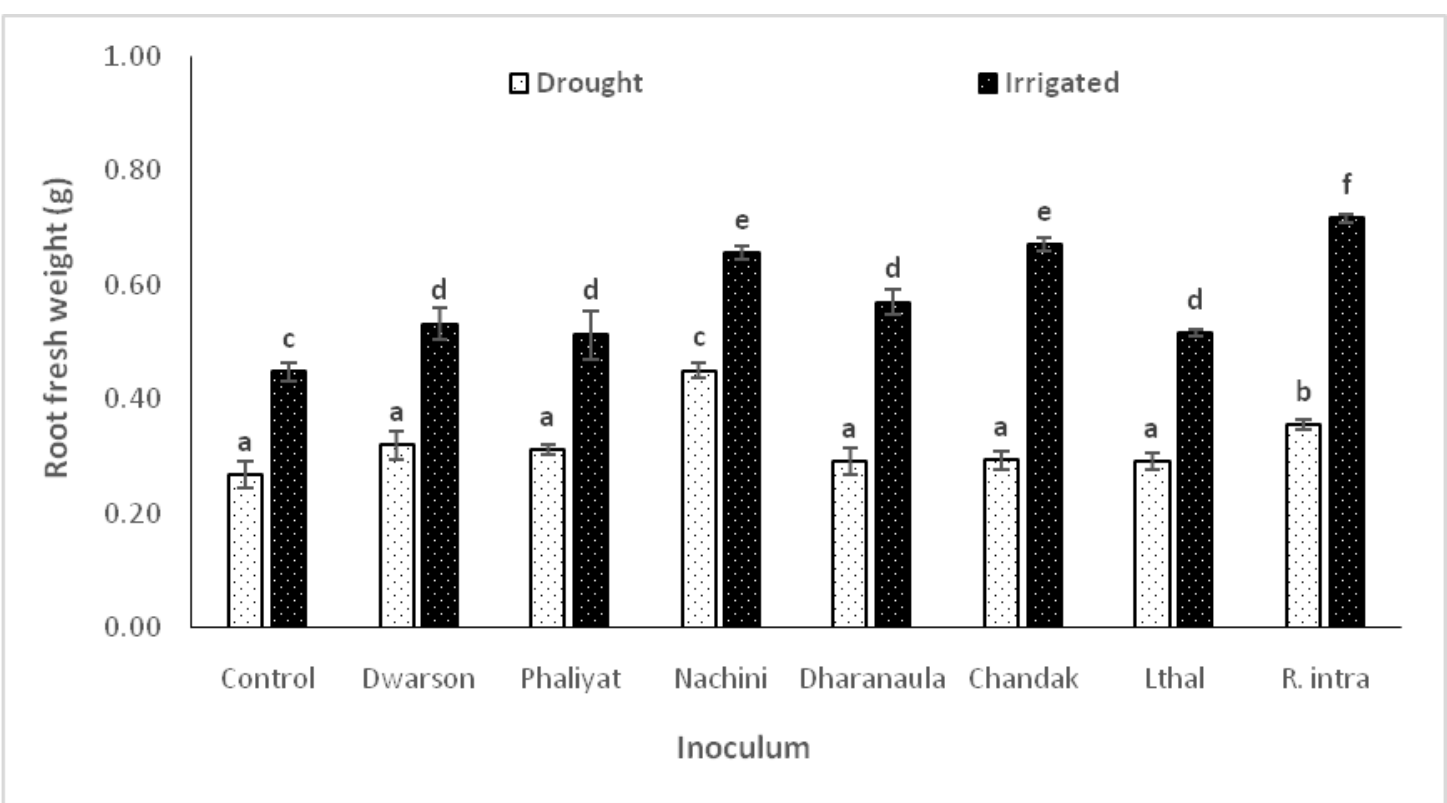


Fig.7 Effect of inoculum developed by trap culturing of native AMF population on the root dry weight of finger millet plants under irrigated and water stressed conditions. Values are the means of 3 replicates \pm S.E. Values with different alphabets are significantly different at $p<0.05$

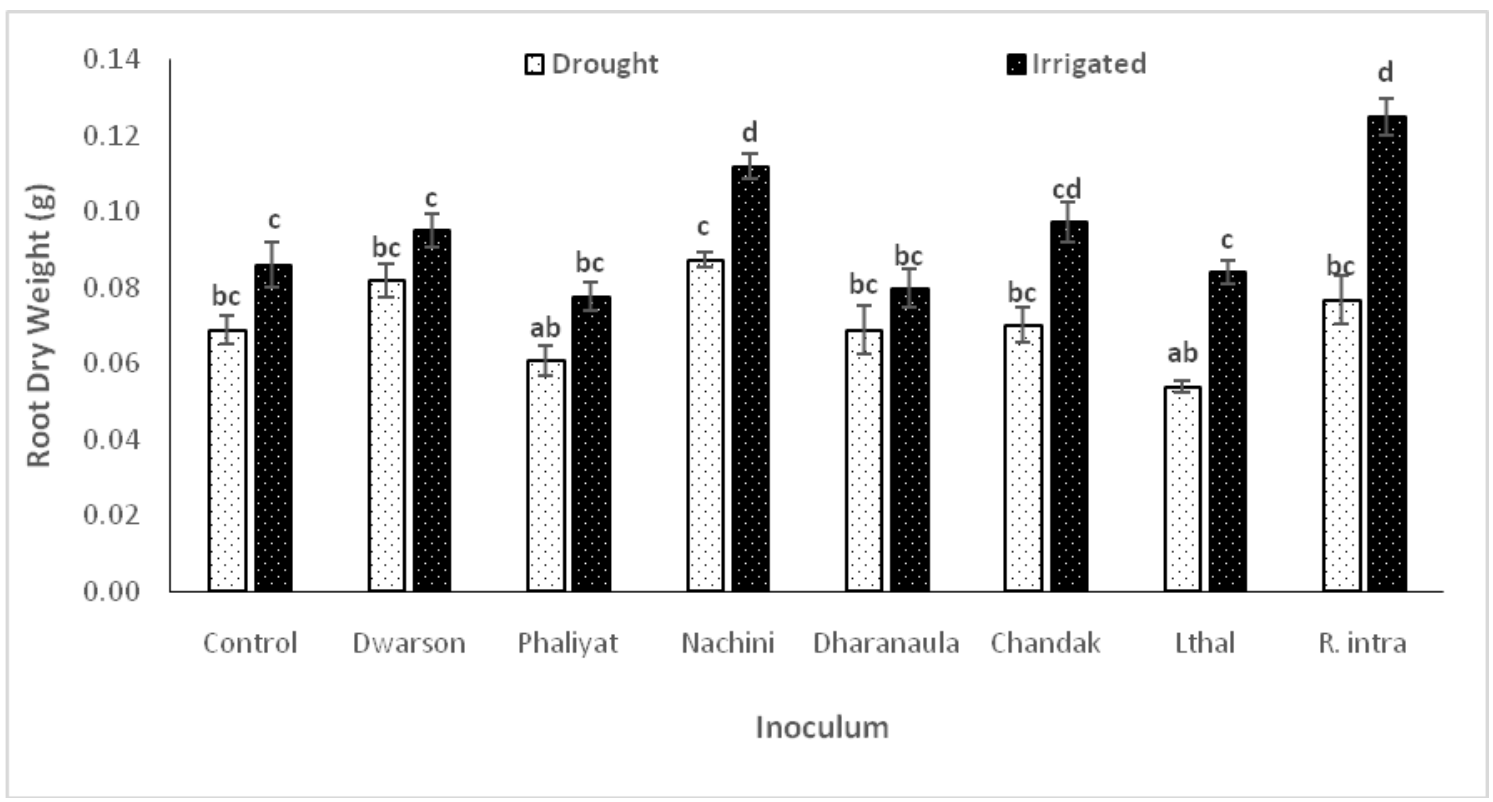

Fig.8 Effect of inoculum developed by trap culturing of native AMF population on the Nitrogen $(\%)$ of finger millet plants under drought and irrigated conditions. Values are the means of 3 replicates \pm S.E. Values with different alphabets are significantly different at $p<0.05$

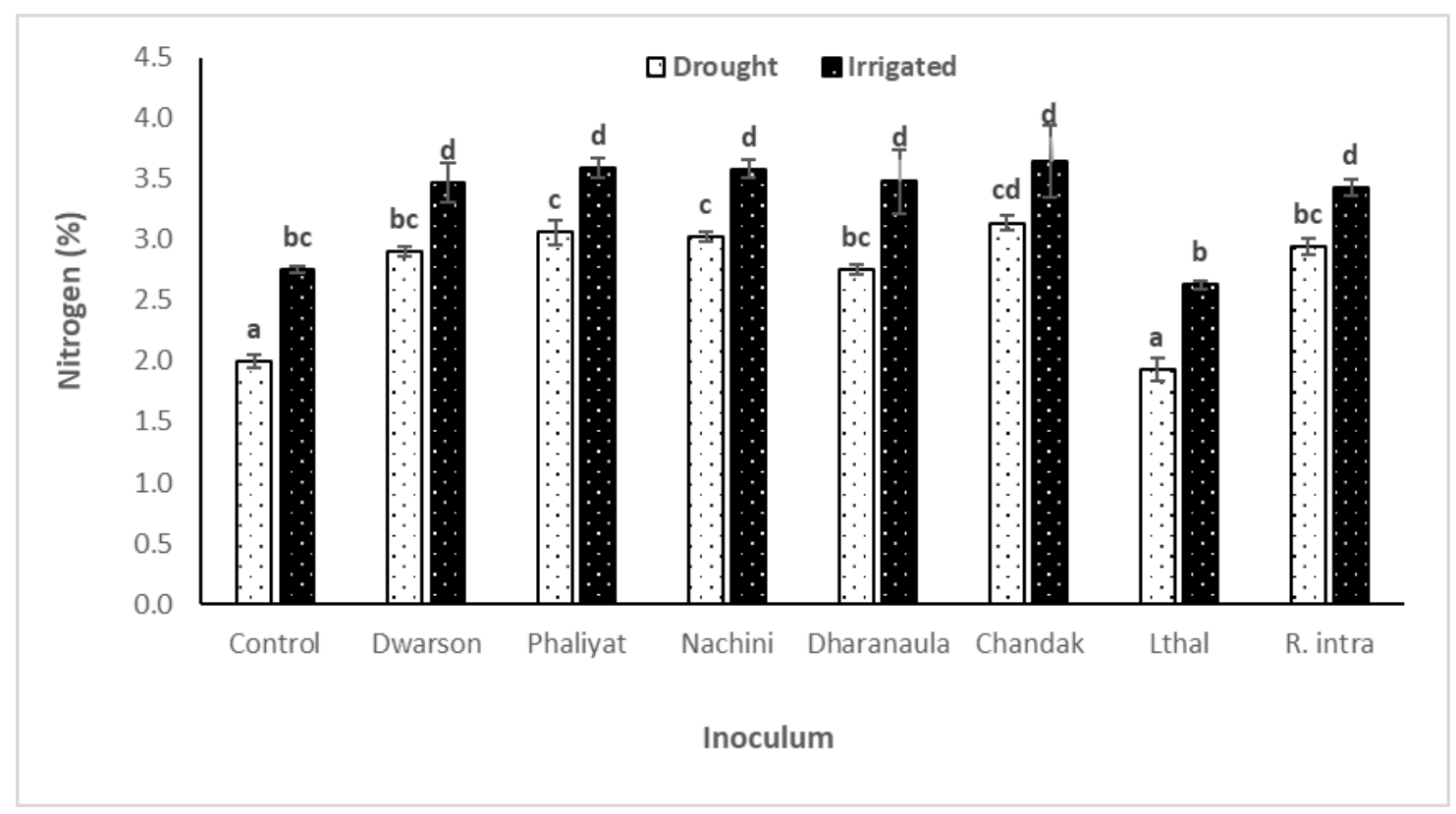


Fig.9 Effect of inoculum developed by trap culturing of native AMF population on the Phosphorus (\%) of finger millet plants under drought and irrigated conditions. Values are the means of 3 replicates \pm S.E. Values with different alphabets are significantly different at $p<0.05$

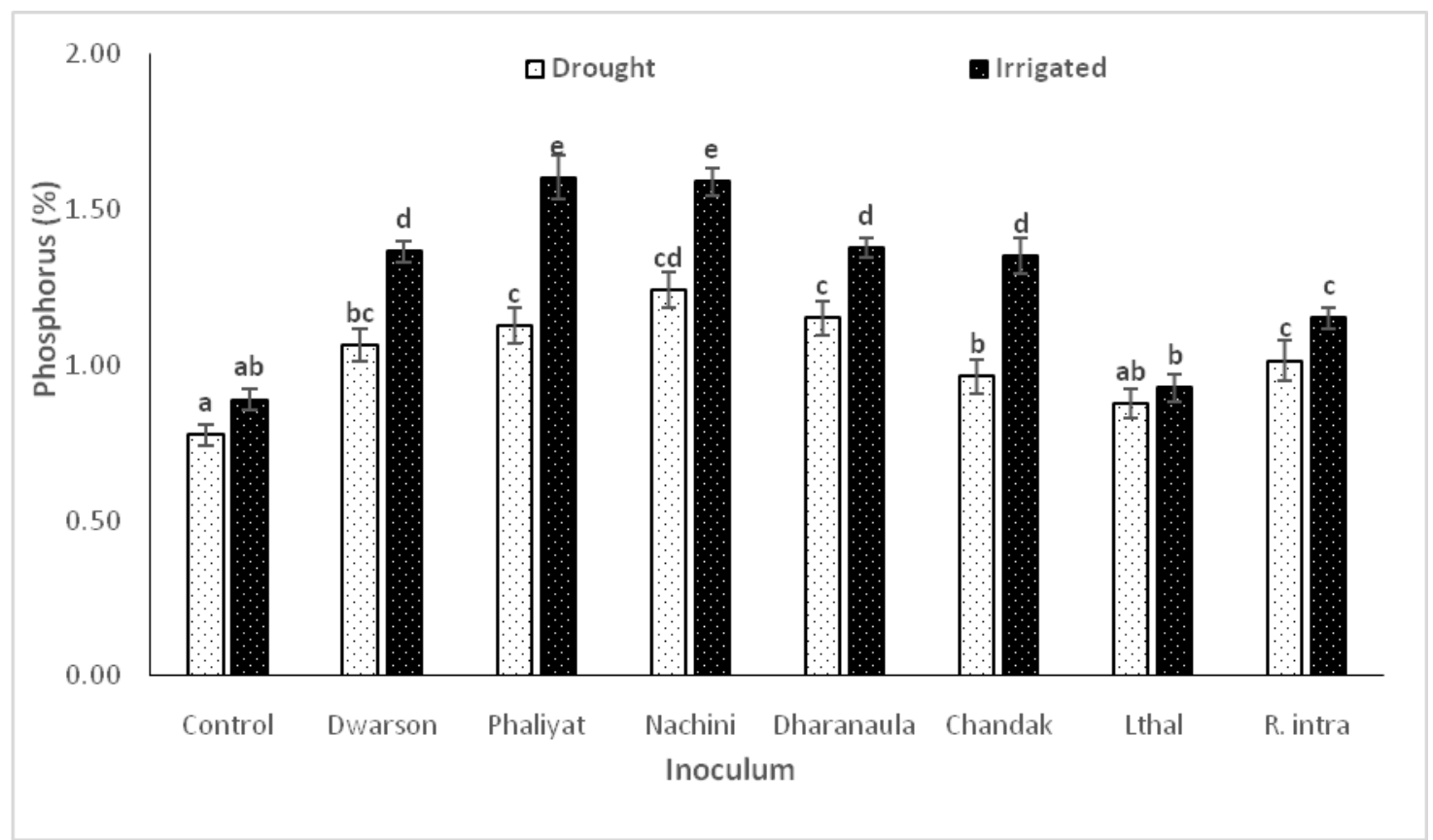

Fig.10 Effect of inoculum developed by trap culturing of native AMF population on the Potassium (\%) of finger millet plants under drought and irrigated conditions. Values are the means of 3 replicates \pm S.E. Values with different alphabets are significantly different at $p<0.05$

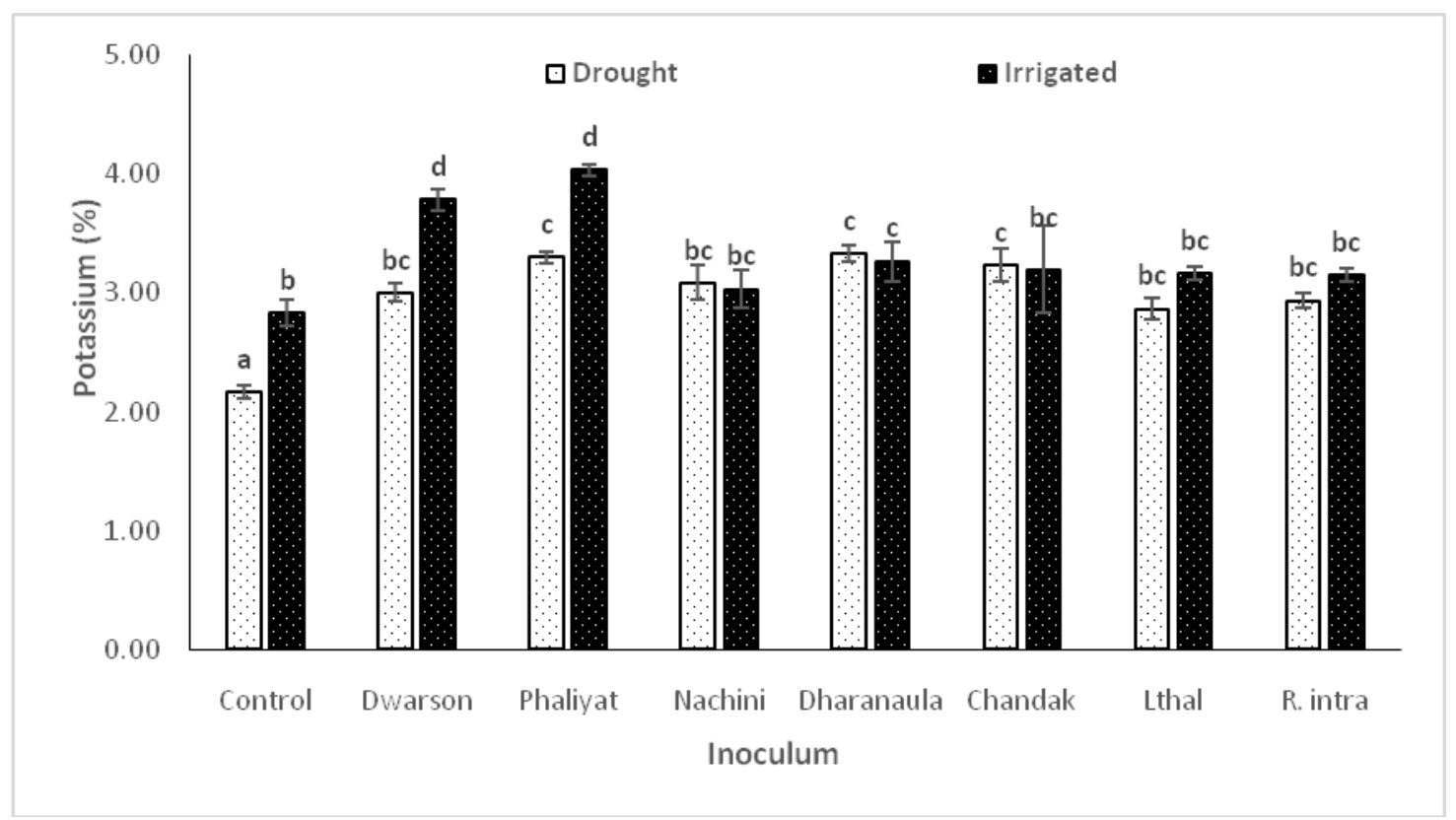


Fig.11 Effect of inoculum developed by trap culturing of native AMF population on the Calcium $(\%)$ of finger millet plants under drought and irrigated conditions. Values are the means of 3 replicates \pm S.E. Values with different alphabets are significantly different at $p<0.05$

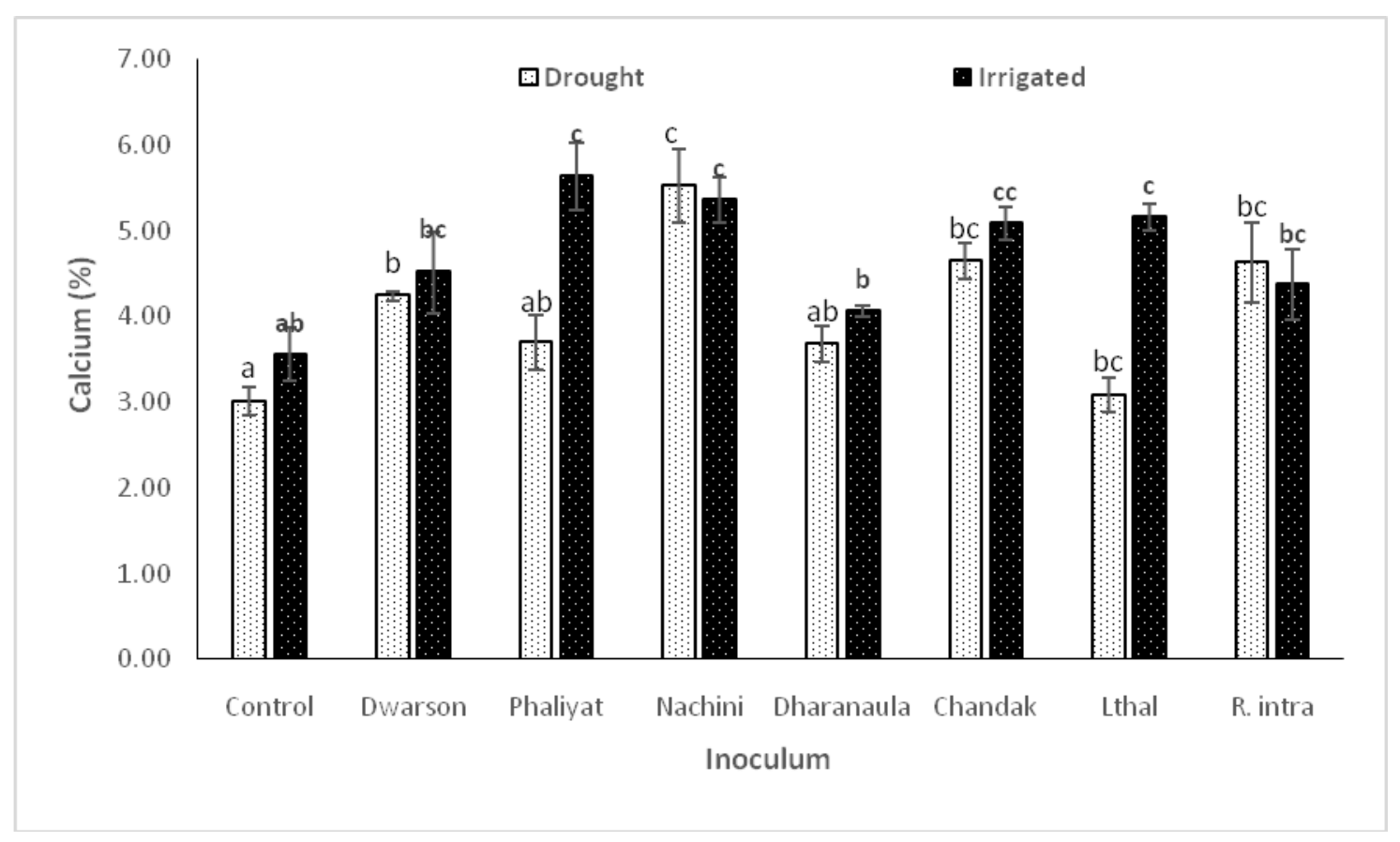

Fig.12 Effect of inoculum developed by trap culturing of native AMF population on the Sodium $(\%)$ of finger millet plants under drought and irrigated conditions. Values are the means of 3 replicates \pm S.E. Values with different alphabets are significantly different at $p<0.05$

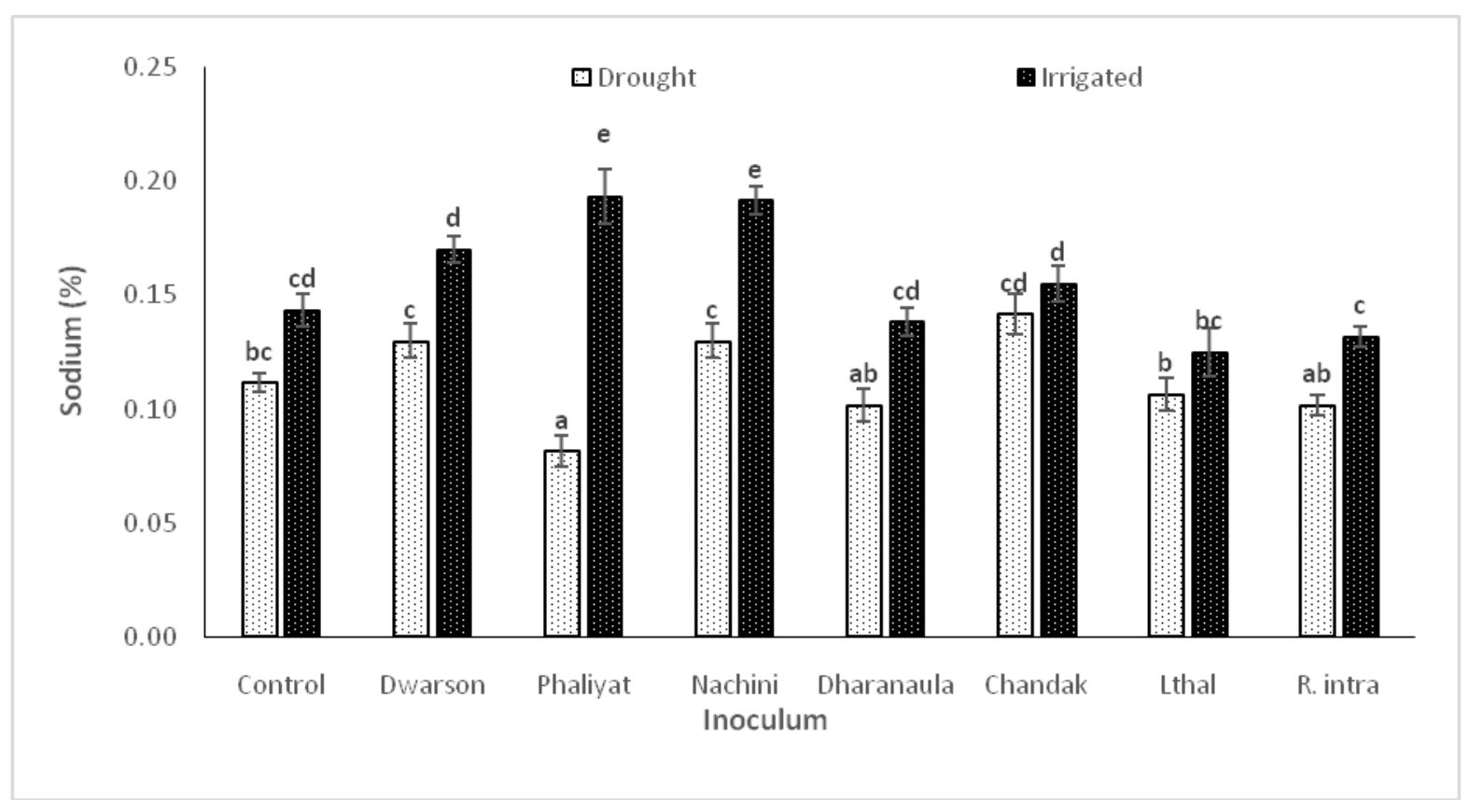


Fig.13 Effect of inoculum developed by trap culturing of native AMF population on the SOD (Unit/mg FW) of finger millet plants under drought and irrigated conditions. Values are the means of 3 replicates \pm S.E. Values with different alphabets are significantly different at $\mathrm{p}<0.05$

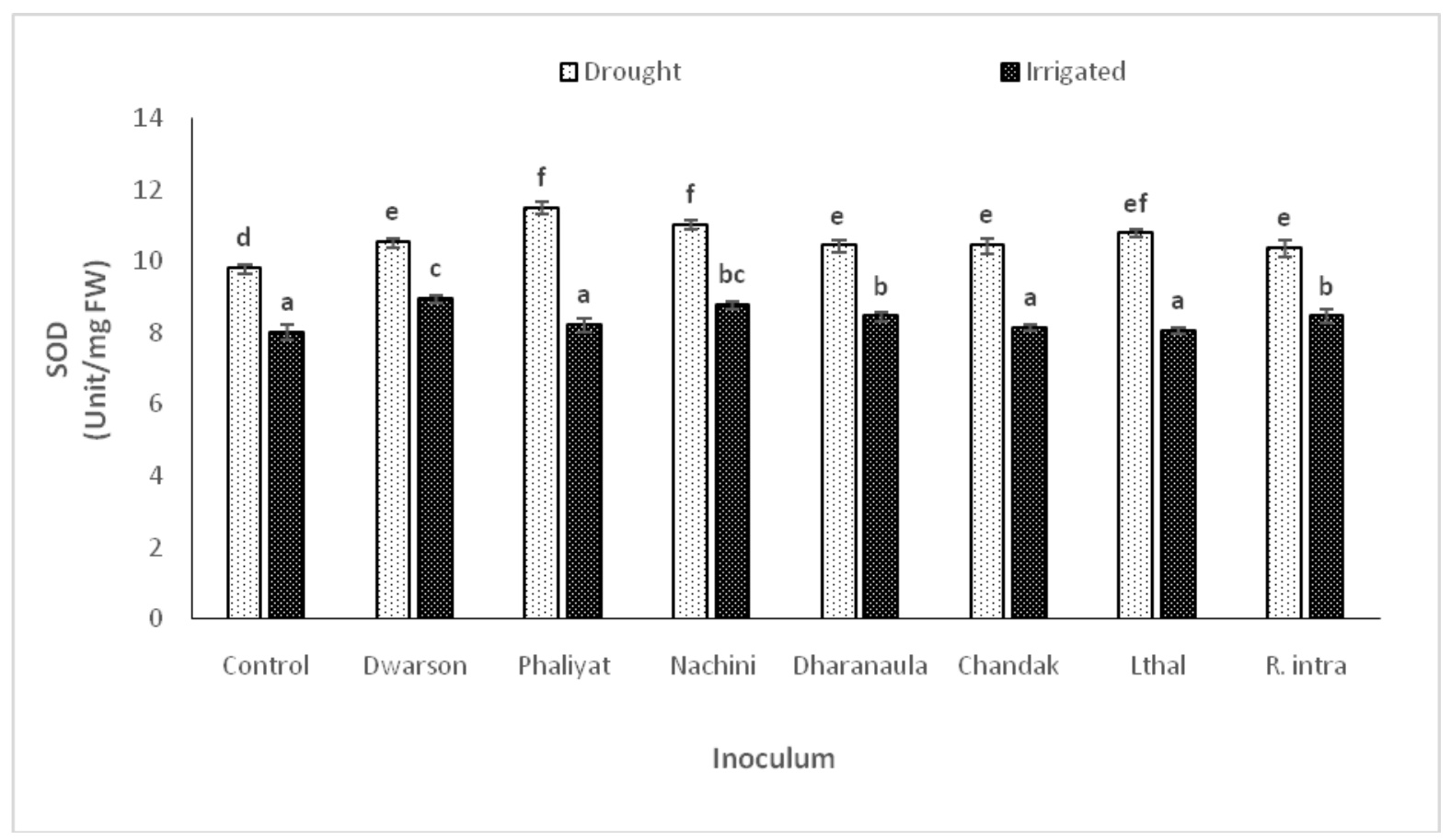

Fig.14 Effect of inoculum developed by trap culturing of native AMF population on the MDA $(\mu \mathrm{g} / \mathrm{g} \mathrm{FW})$ of finger millet plants under drought and irrigated conditions. Values are the means of 3 replicates \pm S.E. Values with different alphabets are significantly different at $p<0.05$

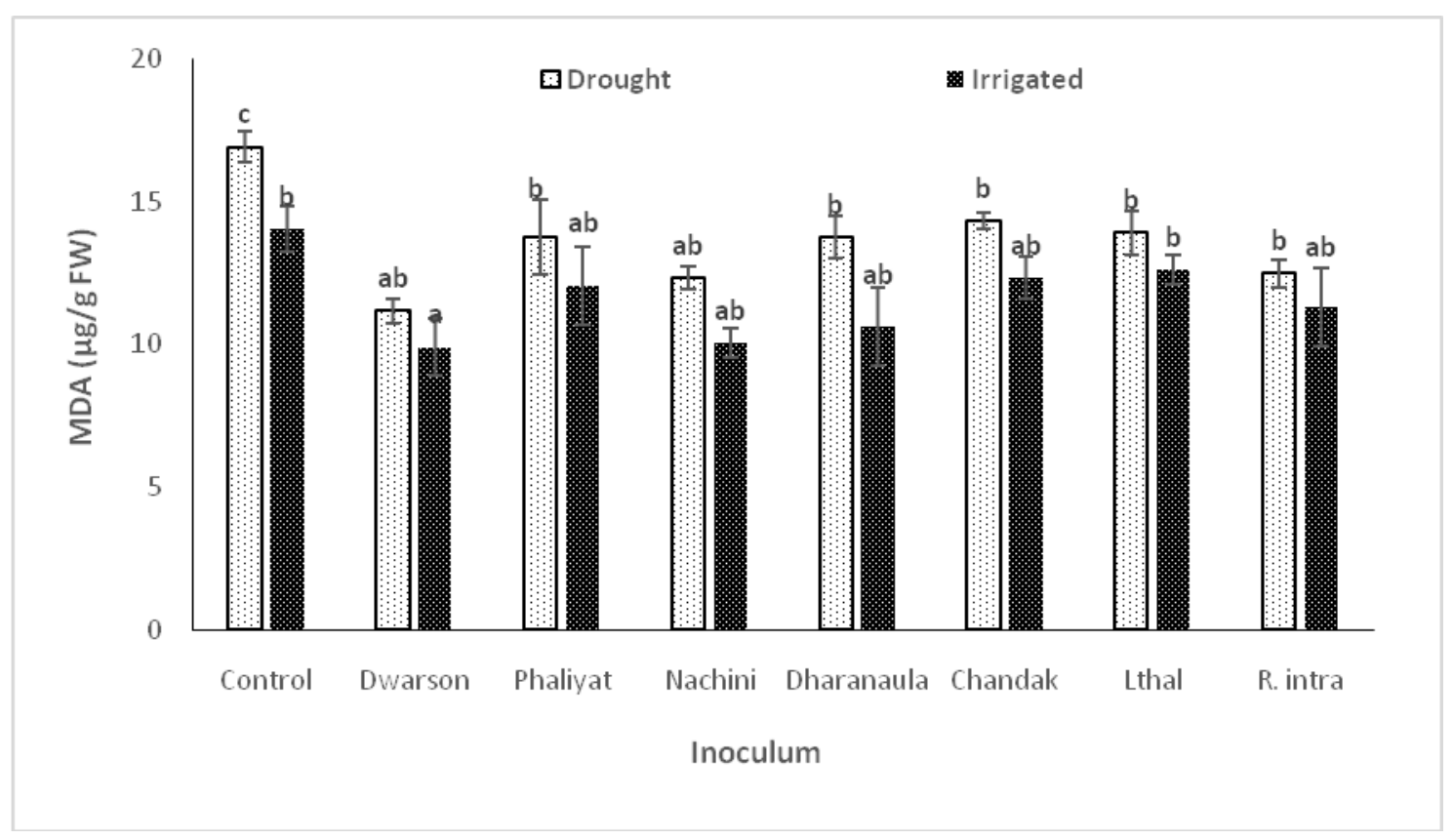


Fig.15 Effect of inoculum developed by trap culturing of native AMF population on the Proline content $(\mu \mathrm{g} / \mathrm{g} \mathrm{FW})$ of finger millet plants under drought and irrigated conditions. Values are the means of 3 replicates \pm S.E. Values with different alphabets are significantly different at $p<0.05$

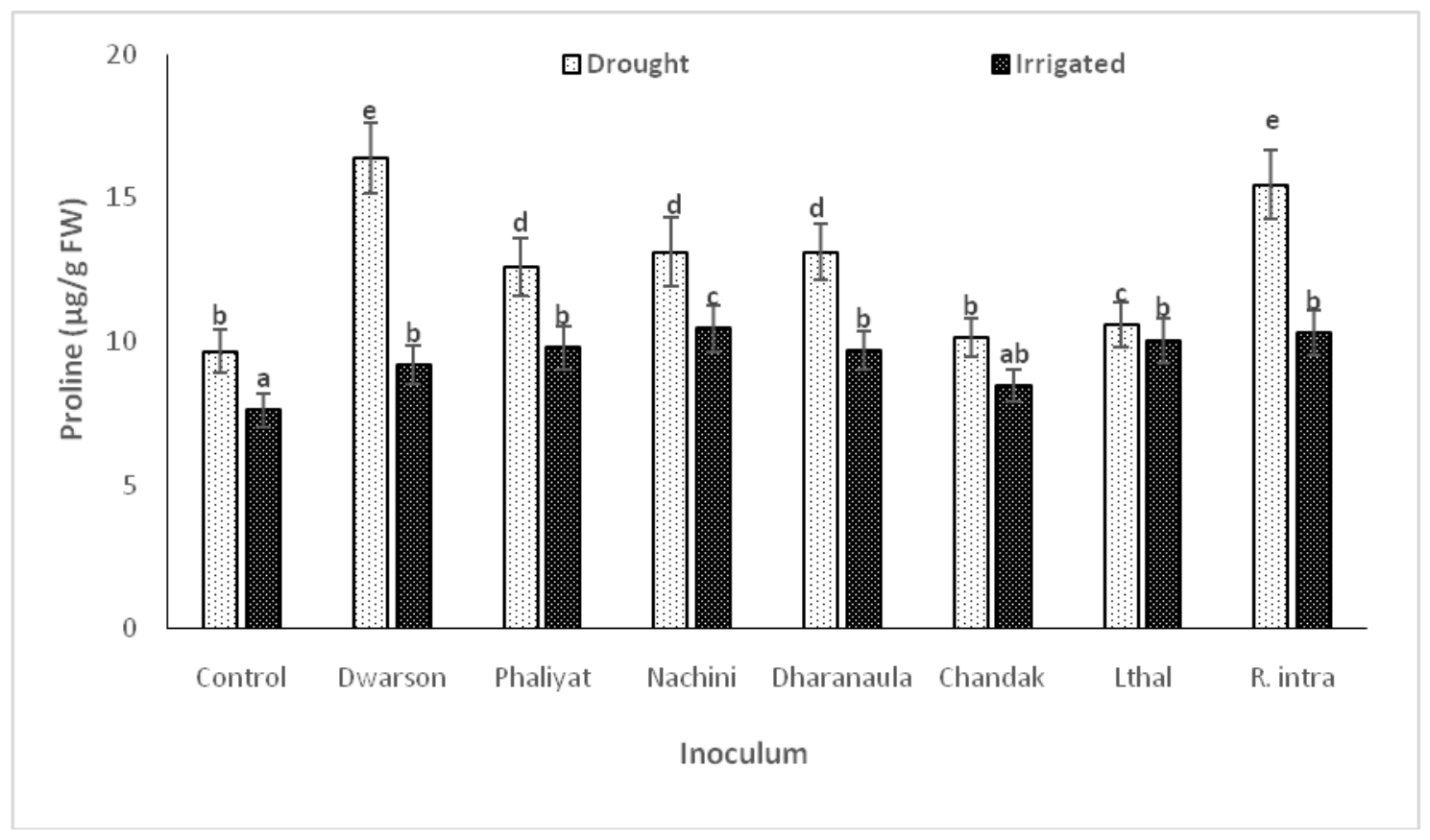

Fig.16 Effect of inoculum developed by trap culturing of native AMF population on the $\mathrm{H}_{2} \mathrm{O}_{2}$ level $(\mu \mathrm{mol} / \mathrm{g} \mathrm{FW})$ of finger millet plants under drought and irrigated conditions. Values are the means of 3 replicates \pm S.E. Values with different alphabets are significantly different at $p$ $<0.05$

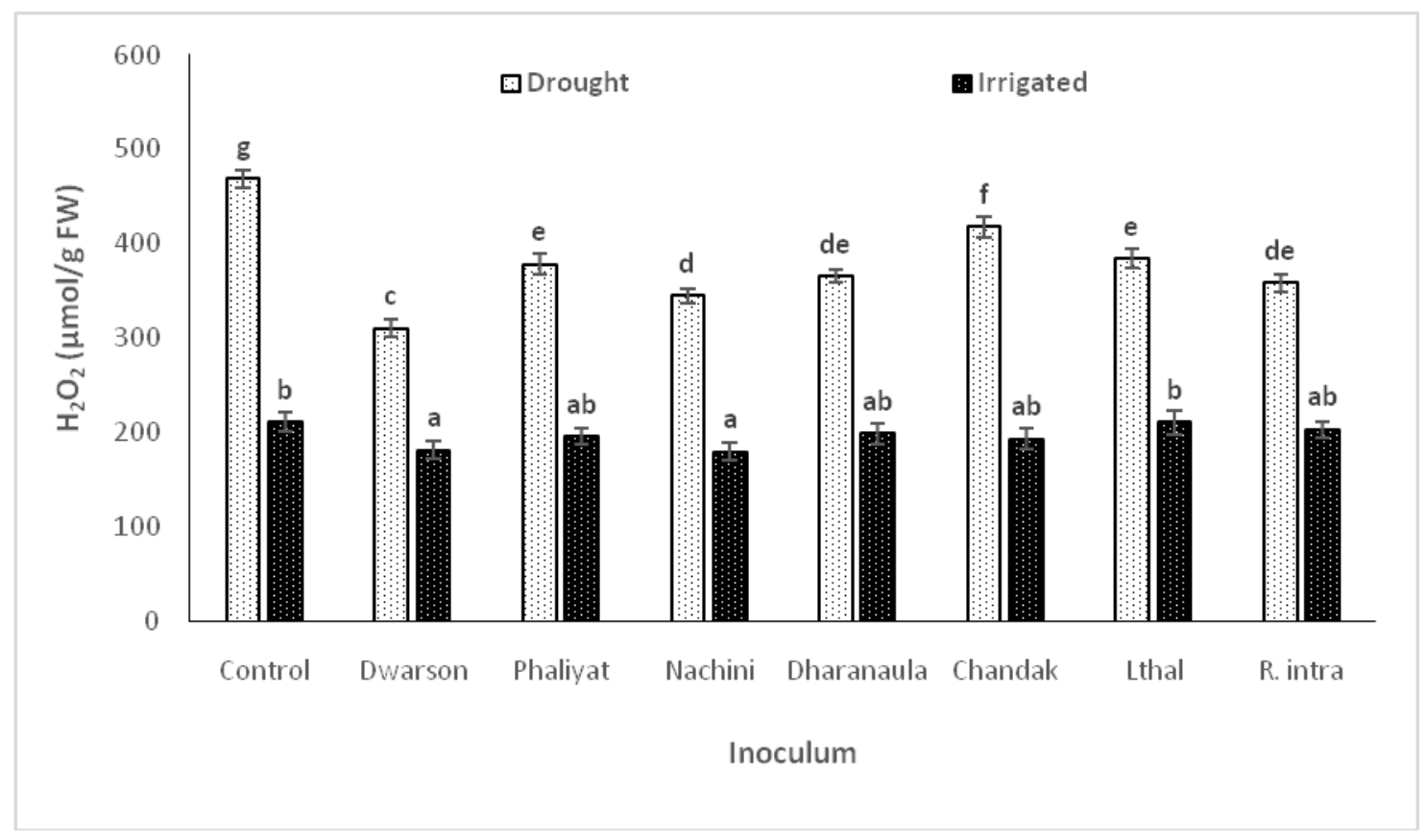


Thus, AMF strengthened the mechanisms involved in drought tolerance of carob by improving water relations, increasing cell wall rigidity, and enhancing oxidative stress alleviation.

The results showed the extent of drought implications on growth of finger millet. Water stress resulted in reduced biomass, nutritional and biochemical status of finger millet plants. On the other hand, the developed native mycorrhizal inoculums elevated the morphological, nutritional and the biochemical status of finger millet plants under both well-watered and water stressed conditions. We found enhanced phosphorous in mycorrhized plants under both well-watered and severe stress conditions, and similar finding was previously observed in many other plant species (Burghelea et al., 2015).The results also indicate if not better, native AMF are capable of growth promotion of same extent as commercially exploited $R$. intraradices. The response varied among the inoculums, however, Dwarson and Nachini remained the most effective inoculum as evident by the enhancement of most of the parameters studied by their inoculation.

\section{References}

Alexieva, V., Sergiev, I., Mapelli, S. and Karanov, E. 2001. The effect of drought and ultraviolet radiation on growth and stress markers in pea and wheat. Plant Cell Environ. 24: 13371344.

Bagyaraj, D. J. 1992. Vesicular-arbuscular mycorrhiza: application in agriculture. Method Microbiol.24: 359-373.

Bates, L.S., Waldren, R.P. and Teare, I.D. 1973. Rapid determination of free proline for water-stress studies. Plant Soil. 39: 205-207

Beauchamp, C. and Fridovich I. 1971. Superoxide dismutase: improved assays and an assay applicable to acrylamide gels. Ann. Biochem. 44: 276-287.

Bradford, M.M. 1976. A rapid and sensitive method for the quantification of microgram quantities of protein utilizing the principle of protein-dye binding. Anal. Biochem. 72: 246-254.

Burghelea, C. Zaharescu, D. G. Dontsova, K. Maier, R. Huxman, T. Chorover, J.(2015)Mineral nutrient mobilization by plants from rock: influence of rock type and arbuscular mycorrhiza. Biogeochemistry. 124: 187-203.

Essahibi, A., Benhiba, L., Babram, M. A., Ghoulam, C., and Qaddoury, A. (2018). Influence of arbuscular mycorrhizal fungi on the functional mechanisms associated with drought tolerance in carob (Ceratonia siliqua L.). Trees, 32(1), 87-97.

Gaur, A. 1997.Inoculum production technology development of vesiculararbuscular mycorrhizae (Doctoral dissertation, Ph. D. Thesis. University of Delhi, Dehli, India).

Gaur, A. and Adholeya, A. 2002. Arbuscularmycorrhizal inoculation of five tropical fodder crops and inoculum production in marginal soil amended with organic matter. Biol. Fert. Soils. 35(3): 214218.

Harris-Valle, C., Esqueda, M., Gutiérrez, A., Castellanos, A. E., Gardea, A. A., and Berbara, R. (2018). Physiological response of Cucurbita pepo var. pepo mycorrhized by Sonoran desert native arbuscular fungi to drought and salinity stresses. Brazilian Journal Microbiology, 49(1), 45-53.

Heath, R.L. and Packer, L. 1968. Photoperoxidation in isolated chloroplasts: I. Kinetics and stoichiometry of fatty acid peroxidation. Arch. Biochem. Biophysic. 125: 189-198. 
Kishor, P.K., Sangam, S., Amrutha, R.N., Laxmi, P.S., Naidu, K.R., Rao, K.R.S.S., Rao, S., Reddy, K.J., Theriappan, P. and Sreenivasulu, N. 2005. Regulation of proline biosynthesis, degradation, uptake and transport in higher plants: its implications in plant growth and abiotic stress tolerance. Curr Sci 88(3):424-438.

Maiti, D., Barnwal, M. K., Singh, R. K. and Variar, M. 2009. A new protocol for on-farm production of arbuscular mycorrhizal mass inoculum of rainfed upland rice. Indian Phytopath. (62): 31-36.

Oehl, F., Silva, G.A., Goto, B.T. and Sieverding, E. 2011 Glomeromycota: three new genera, and glomoid species reorganized. Mycotaxon 116: 75-120 doi: 10.5248/116.75

Petipas, R. H., González, J. B., Palmer, T. M., and Brody, A. K. (2017). Habitatspecific AMF symbioses enhance drought tolerance of a native Kenyan grass. Acta oecologica, 78, 71-78.

Querejeta, J. I., Allen, M. F., Caravaca, F., and Roldán, A. (2006). Differential modulation of host plant $\delta 13 \mathrm{C}$ and $\delta 180$ by native and nonnative arbuscular mycorrhizal fungi in a semiarid environment. New Phytologist, 169(2), 379-387.

Smith, S. E. and Read, D. J. 1997. Mycorrhizal Symbiosis. Academic Press, New York.

Tewari, L., Johri, B.N. and Tandon, S.M., 1993. Host genotype dependency and growth enhancing ability of VA- mycorrhizal fungi for Eleusine coracana (finger millet). World $\mathrm{J}$. Microbiol. Biotech. 9(2):191-195.

Trouvelot, A., Kough, J., Gianinazzi-Pearson, V. 1986. Evaluation of VA infection levels in root systems V. GianinazziPearson, S. Gianinazzi (Eds.), Research for estimation methods having a functional significance, Physiological and Genetical Aspects of Mycorrhizae. INRA Press, Paris, France 217-221

Tyagi, J., Shrivastava, N., Sharma, A. K., Varma, A., and Pudake, R. N. (2018). Mycorrhiza Fungus Rhizophagus intraradices Mediates Drought Tolerance in Eleusine coracana Seedlings.

Van Der Heijden, M. G. and Scheublin, T. R. 2007. Functional traits in mycorrhizal ecology:their use for predicting the impact of arbuscular mycorrhizal fungal communities on plant growth and ecosystem functioning. New Phytol.174(2): 244-250

Wu, H. H., Zou, Y. N., Rahman, M. M., Ni, Q. D., and Wu, Q. S. (2017). Mycorrhizas alter sucrose and proline metabolism in trifoliate orange exposed to drought stress. Scientific reports, 7:42389.

Zhang, Y., Zhong, C. L., Chen, Y., Chen, Z., Jiang, Q. B., Wu, C., and Pinyopusarerk, K. (2010). Improving drought tolerance of Casuarina equisetifolia seedlings by arbuscular mycorrhizas under glasshouse conditions. New Forests, 40(3):261271.

\section{How to cite this article:}

Pallavi and Sharma, A.K. 2019. Evaluation of Native AMF Population for Drought Stress Ameliorating Potential in Finger Millet. Int.J.Curr.Microbiol.App.Sci. 8(11): 1348-1363. doi: https://doi.org/10.20546/ijcmas.2019.811.158 